\title{
幼児におけるジェスチャーの視点 認知的役割取得能力との関連
}

\author{
片 山顕 裕* 針 生 悦子**
}

発話に伴うジェスチャーには, 主観的視点のものと客観的視点のものの 2 種類がある (Özyürek, 2000)。これまでの研究で, 大人では聞き手の理解状態に配慮する時には客観的視点のジェスチャーが増 え (藤井, 2000), 発達的には年齢が高くなるほど客観的視点のジェスチャーが増えること (藤井, 1999), な どが指摘されてきた。子どもは，発達に伴い，聞き手がどれだけのものを見せられればどれだけのこと を知ることができるかが分かるようになり，それで，ジェスチャーにおいても客観的視点のものをより 多く産出するようになるのだろうか。これが本研究の仮説であり, 対象児は幼児 43 名であった。幼児 は, 認知的役割取得課題によって, 聞き手の理解状態に敏感なレベル(レベル2)と, まだあまり敏感でな いレベル(レベル1) とに分けられた。結果として, レベル 2 の子どもでは, レベル 1 の子どもに比べ, 客 観的視点のジェスチャーが多いことが明らかになった。ここから, 子どもが他者の認知状態をモニター する能力と, 客観的視点のジェスチャーを産出することとの間には, 関連があることが示唆された。

キーワード : ジェスチャーの視点, 認知的役割取得能力, 心の理論, 幼児, 説明課題

\section{問 題}

日常的なコミュニケーション場面では，話者がある 思考内容を他者に伝達しようとする際に身体の動きが 発現することがあるが, こうした身体の動きはジェス チャーと呼ばれる。ジェスチャーは言語・非言語音声 情報・表情などとともに, コミュニケーションにおい て重要な役割を果たしている。というのも, ジェス チャーの多くは, 時空間的隣接性および類似性によっ て対象を表現するものであり，それゆえ話者のある種 イメージ的な心的表象を源として生成されていると考 えることができるからである(喜多, 2002)。したがって， ジェスチャーを観察することによって, 話者が表現す る事柄に対してどのようなイメージを思い浮かべてい るのか, すなわちどのような認知状態にあるのかが推 測できる(McNeill, 1985, 1987, 1992)。

このように, McNeill (1985) 以降の研究では, 話者 のジェスチャーの産出が, 話者自身の認知機能との関 係において注目されてきた。しかし，自然なコミュニ ケーション場面には, 聞き手が存在し, そのことも話

* 東京大学大学院教育学研究科

現所属：侏日本総研ソリューションズ

テ113-0854 東京都文京区本郷7-3-1

** 東京大学大学院教育学研究科
者のジェスチャー産出に影響を与えている。それゆえ， 近年では, ジェスチャーの産出はコミュニケーション 相手の存在に影響を受ける, という点についても注目 されている(藤井, 2002)。このような関心に沿った研究 としては, 例えば,開眼者・開眼者目隠し群・中途失明 者・先天盲者のジェスチャーを比較し, 生起頻度がこ の順で減少することを示した, 佐々木 (1993) が挙げら れる。また，Özyürek (2000) は，聞き手の人数や聞き 手との位置関係によって, 産出されるジェスチャーの 向きが変化することを明らかにした。このように, 話 者は, 聞き手との関係によって, ジェスチャーの生起 頻度や向きを調整することが明らかになっているが， 話者が聞き手の存在によって調整することが指摘され ている,もう一つの重要なジェスチャーの側面として は, 視点が挙げられる (藤井, 2002)。

藤井 (1999) は,このジェスチャーの視点に関して, 表現対象をどのような視点で捉えてイメージ化し, 聞 き手に示そうかとしているかによって，主観的視点と 客観的視点の 2 種類に分類している。それによれば, 主観的視点のジェスチャーとは, 身体をジェスチャー に組み込んで自分を中心として対象を捉え, 身体の前 後左右に大きく描くものであるのに対し, 客観的視点 のジェスチャーは, 表現対象を外側から捉え, 身体の 前でミニチュアのように描くものであり，それぞれの 典型例として, ブランコについての表現が挙げられて いる。主観的視点のジェスチャーとは, あたかも自分 
がブランコに乗っているかのような視点で, 身体の横 に 2 本のチェーンを描き，身体の下に椅子を示すよう な表現である。他方, 客観的視点のジェスチャーは, 話者の身体の前方空間のみを使って行われ, 肩の位置 から腹の位置まで 2 本のチェーンを描き, 腹の前で座 るところを描くようなものが典型で, ブランコを実物 のミニチュアのように表現するものである。

話者がどちらの視点のジェスチャーを行うかが, 聞 き手の存在によって影響を受ける可能性があることを 示したものとしては, 以下の研究が挙げられる。藤井 （2000）は，話者が聞き手にある事柄を説明する際に， 対面状況（聞き手の顔が見える状況）と非対面状況（聞き手 の顔が見えない状況）において，ジェスチャーの視点ごと の生起頻度を比較し, 対面状況か非対面状況かによっ て, 主観的視点のジェスチャーの生起頻度は変化しな いが, 客観的視点のジェスチャーの生起頻度が対面状 況において増加することを明らかにした。また，藤井 (2002) は，成人を対象に，聞き手の存在を想定するか どうかで, ジェスチャーの視点の使われ方に変化が見 られるかどうかを検討した。その結果, 聞き手が自分 を見ることを想定した条件では，聞き手が自分を見る ことを想定していない条件よりも客観的視点のジェス チャーが多く産出されていることが明らかになった。

このように,これまでの研究においては, ジェス チャーの視点も, 話者が聞き手の存在を意識するかど うかによって影響されることが見いだされてきた。こ れは, 聞き手への配慮の程度によって, ジェスチャー の視点が個人内で変動するということだが, 聞き手に 対する配慮の程度は, 個人内だけでなく, 発達的にも 変化する。すなわち, 聞き手の存在を意識し, その聞 き手が何らかの事柄を「知る」ためにはどういった情 報が必要であるかについての理解は, 発達とともに進 むことが示されている (Chandler \& Helm, 1984 ; Flavell, Botkin, Fry, Wright, \& Jarvis, 1968 ; Taylor, 1988)。そのよ うな他者理解の発達と, どのような視点のジェス チャーをするかということとのあいだに関連があると すれば, ジェスチャーも, 発達に伴い客観的視点のも のが増加することが予想される。

実際, ジェスチャーの視点の発達的変化について, 藤井 (1999) は, 対面相互作用場面で事物を説明する際 に産出されたジェスチャーを発達的に比較し, 幼児と 大学生とでは同じ対象について説明する際にも, 異な る視点のジェスチャーを用いて表現することを指摘し た。すなわち, 幼児では, 主観的視点のジェスチャー が多く用いられるのに対し, 大学生は客観的視点の
ジェスチャーを主に使用することが明らかになった。 また, McNeill (1992)によると，12ヶ月から 18ヶ月の 子どもが使用するジェスチャーは, Werner \& Kaplan (1963) が指摘したように, 本質的には表現しようとし ている内容の “上演”であり，自分の身体がジェス チャーの中に組み込まれている。例えば, McNeill (1992)は，幼児にアニメーションを見せた後にそれに ついての話をさせると，全身を使って登場人物の動き を模做する場合があることを指摘している。McNeill (1992)において，このような演技的なジェスチャーは 「登場人物の視点」によるジェスチャーと呼ばれてい るのに対し，手が登場人物や対象物を表すといったよ うに，身体 (主に手) が他の象徵としての役割を果たす ジェスチャーは「観察者の視点」によるジェスチャー と呼ばれている。これらのジェスチャーは，それぞれ 藤井 (1999) の「主観的視点」のジェスチャーと「客観 的視点」のジェスチャーに対応すると考えられ，その 意味で McNeill (1992)も，年少の子どもにおいては主 観的視点のジェスチャーがより高頻度で出現すること を指摘した研究の一つと言える。

以上のように，ジェスチャーの視点は主観的なもの から客観的なものへと発達的に移行する，ということ が報告されている。これまで,こうした発達的現象を 引き起こしている要因についての実証的な検討はなさ れてこなかったが, 上述したように，ジェスチャーの 産出に聞き手の存在を意識することが影響していると すれば，幼児と大人との違いは，この聞き手の存在を 意識する程度にあるのかもしれない。すなわち，幼児 において主観的視点のジェスチャーがより多く用いら れるということは，幼児はジェスチャーを産出する際 に, 聞き手である他者の存在をあまり意識していない, ということが考えられる。

実際,これまで主に「心の理論」研究において,「知 る」「知っている」とはどういうことか, 知識は何に由 来するのかという基本的な認識論的問題に関する素朴 理論の発達が検討され (斉藤, 2000), その中で, 幼児に とって, 他者の視点や信念の理解が困難であることが 繰り返し示されてきた。他者とのコミュニケーション 場面に関連したところでも，幼児は，他者である聞き 手が何らかの事柄を「知る」ためにはどういった情報 が必要であるかについての理解が十分ではないことが 示されている (Chandler \& Helm, 1984 ; Flavell et al., 1968 ; Taylor, 1988)。

そこで本研究では，コミュニケーション場面におい て産出されるジェスチャーの視点には, 「聞き手が何か 
を知るためにはどういった情報を与える必要がある か」についての理解の程度が影響を与える可能性につ いて, より直接的に検討する。すなわち, 先行研究で 見られたようなジェスチャーの視点における発達的移 行には, この理解の程度に関する発達的差異が関連し ているかどうかをみることにする。

この「聞き手が何かを知るためにはどういつた情報 を与える必要があるか」を理解する能力のことを, こ こでは山岸 (1980) や松村 $(1983,1984)$ を参考に, 認知的 役割取得能力と呼んでいくことにする。Taylor (1988) は，この能力に関して幼児をレベル 1 とレベル 2 とい う 2 つの発達段階に分類している。それによれば, レ ベル 1 の段階にある子どもは, 他者の認知プロセスを あまり理解していないので, 他者がある事柄を知るた めには, 例えば視覚的情報が重要であるということは 分かってはいるが, 視覚的情報が与えられさえすれば, その質がどのようなものであれ他者は知ることができ ると考える。これに対し, レベル 2 の子どもは, 他者 の認知プロセスについての理解が進むので, 他者が知 るためには視覚的情報にアクセスするだけでは十分で はなく，どういった視覚的情報が重要であるかを正し く理解できる。

そこで, 本研究では, 幼児において, 他者が何かを 「知る」ためにはどういった情報を与える必要がある のかについての理解の程度, つまり認知的役割取得能 力と, 主観的および客観的視点のジェスチャーの生起 との関連を実証的に検討する。そして, 認知的役割取 得能力がレベル 2 の段階にある幼児の場合, レベル 1 の段階にある幼児に比べて，コミュニケーション場面 において，主観的視点のジェスチャーは少なく，客観 的視点のジェスチャーは多く観察されるだろう, とい うのがここでの予測である。

\section{方 法}

\section{対象児}

課題は, 都内私立幼稚園に通う年中児 19 名, 年長児 24 名を対象に実施した1。しかし, 認知的役割取得課題 では, 年中児 1 名が, あとに述べる練習課題を通過で

Taylor (1988) によれば, 6 歳頃にレベル 1 とレベル 2 が分 かれる。そこで, 本研究では, 年歯の影響をできるだけ排除 し, 認知的役割取得能力の影響について検討したかったため, 対象児がレベル 1 とレベル 2 とに分かれてくれることを期待 し, レベルの移行が始まり出すだろう年中クラス (5 歳 2ヶ月) と, レベルの移行が本格的になるだろう年長クラス (平均 6 歳 0ヶ月）を対象児とした。
きなかったため, その後の分析から除かれた。また, 説明課題では, ブランコやすべり台について知らない という理由で年中児 4 名が, ビデオカメラ操作の失敗 により年長児 2 名が分析から除かれた。その結果, 認 知的役割取得課題に関しては年中览 18 名 (男 8 女 10 , 平 均 5 歳 2 ヶ月; レンジ 4 歳 7 ヶ月〜 5 歳 6 ヶ月), 年長児 24 名

(男 13 女 11 , 平均 6 歳 0 ケ月; レンジ 5 歳 7 ケ月 6 歳 6 ケ月), 説明課題の分析,認知的役割取得能力と説明課題の関 連の検討に関しては年中児 15 名 (男 7 女 8 , 平均 5 歳 1 ヶ 月; レンジ 5 歳 7 ヶ月 6 歳 6 ヶ月), 年長児 22 名(男 12 女 10 , 平均 6 歳 0 ケ月; レンジ 5 歳 7 月〜 6 歳 6 ケ月) が最終的な分 析対象となった。

材料

認知的役割取得課題 Taylor (1988) の刺激を一部改 変して使用した(FIGURE 1)。この課題では, 透明なプラ スチック板に描かれたゾウの絵, 正方形の空がついて いる紙のカバー(3 枚), 3 体の人形, 箱を用いた。カバー は絵を部分的に遮蔽するために用いられた。箱は人形 を入れておくためのもので，人形は，実験者と対象児 が絵について話しているのを聞いたり, 絵そのものを 見たりできないということを対象児に示すために用い られた。また, 練習課題では, プラスチック板に描か れたアンパンマンとバイキンマンの絵と, 正方形の空 がついている紙のカバーを用いた。

説明課題 説明する相手として 1 体の人形を用いた。 手続き

園内のアトリエで一人ずつ面接を行った。対象児の 入室後, 実験者と向かい合って椅子に座ってもらいラ ポールをとった。ついで, 認知的役割取得課題を行い, その後すぐに説明課題に移った。一人当たりの所要時 間はおよそ 15 分であった。

認知的役割取得課題 練習課題の後, 本課題に移つ た。練習課題では, 対象児はアンパンマンとバイキン マンが描かれた透明のプラスチック板を見せられ，ア ンパンマンとバイキンマンにラベルをつけるよう促さ れた。次に, 実験者は, プラスチック板を実験者と対 象児の間に垂直に立てて, 紙のカバーを実験者の側に かけた。カバーがとりつけられると, 対象児は絵の全 体を見ることができるが，実験者は紙カバーの空から 見える部分しか見ることができなかった。カバーの窓 の位置によって, 実験者には(1)アンパンマンの顔だけ が見える，(2)バイキンマンの顔だけが見える，(3)空か らは何も見えない, という 3 つの場合が設定された。 対象児は，それぞれの場合について実験者からは何が 見えるかを尋ねられた。この練習課題は，カバーにと 


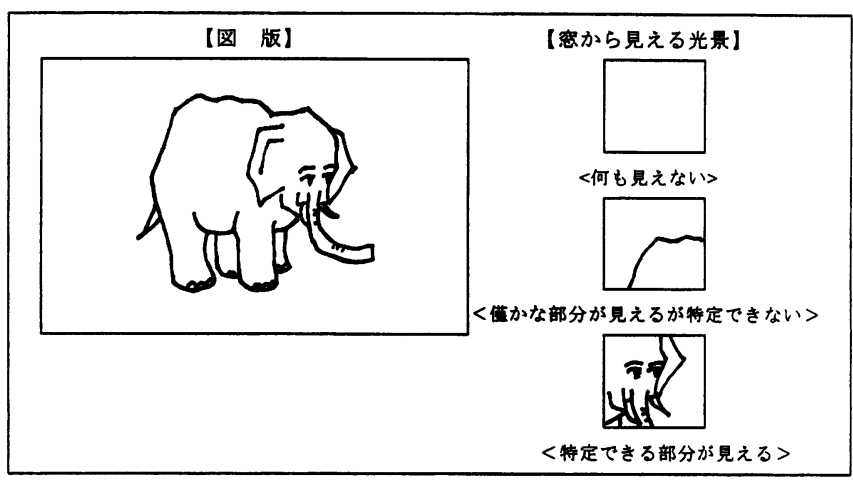

FIGURE 1 認知的役割取得課題の材料

りつけられた空から見える光景が制限されたものであ ることを，対象児が理解しているかどうかをチェック するために行われた。それぞれの質問に対する正答は, (1)アンパンマン(の顔)，(2)バイキンマン(の顔)，(3)何も 見えない，とし，3問全てに正答した場合に理解して いるものとみなした。「対象者」闌でも述べたように， ここで正答を得られなかった年中児 1 名はその後の分 析対象から外された。

本課題では，まず対象児に 1 体の人形が紹介された。 ついで，実験者はあらかじめ用意しておいた箱を取り 出し,その箱に人形を入れ,「この箱に入ると,中は真っ 暗で何も見えないし，何も聞こえなくなっちゃうんだ よ」と対象児に説明した。次に, 実験者はゾウが描か れた透明のプラスチック板を机の上に置き対象児に見 せ, この絵が何であるかを尋ねた。ついで, 実験者は, これから人形にも絵を見せてあげるつもりだが, 僅か な部分しか見えないように絵にカバーをかけるつもり であることを対象児に説明した。カバーは 3 種類あり, まず, 最初のカバーが絵にかけられた。このカバーの 空からは何も見えなかった。この時点で，対象児の見 ている光景は, 人形が見るものと同じであった。実験 者は, 人形を箱の中から取り出し, 空から人形に絵を 見せながら，「(人形の名前)は，今，初めてこの絵を見る んだけど，これが(人形の名前)の見える部分だよ」と対 象児に説明し，空の部分を指さした。そして，「(人形の 名前)は，この絵の中にゾウさんがいるってことが分か るかな？それとも分からないかな？」と尋ねた(あるい は「(人形の名前) は，この絵の中にゾウさんがいるってことが分 からないかな? それとも分かるかな?」と尋ねたが, この順番は 対象児間でカウンターバランスをとった)。対象児が, カバー の窓からは何も見えない場合についての質問に答えた ら，実験者は同様の手続きを以下の 2 つのカバーにつ
いて順に，それぞれ異なった人形を用いて繰り返し $た^{2}$ 。

・僅かな部分が見えるがそれだけでは対象が何である かを特定できない場合

・対象を特定するのに十分な部分が見える場合

説明課題 対象児のジェスチャーを観察するために, 藤井 (1999) に従って，ブランコとすべり台の説明をす るという 2 つの課題を用意した。どちらも，それがど んなものであるかを他者に教えるという説明課題で あった。説明する対象としてこれらを選択したのは, これらの対象は幼児に馴染みが深く, 形と動きがあり, 説明する際にジェスチャーを使用しやすいと考えられ るためである。まずブランコとすべり台についての知 識を確認した後, 人形を見せ「この子はメアリーちゃ んっていうんだけど，まだ小さくてブランコを一度も 見たことがなくて，どんなものか分からないんだって。 だから，(対象児の名前) ちゃんがメアリーちゃんにブラ ンコってどんなものか教えてあげてくれるかな。ブラ ンコってどんなのかな? 」という教示を与えた。実験 者はジェスチャーを行わず，うなずいたり相桘をうっ たりしながら聞いた。その後，すべり台についても同 様の方法で説明を求めた。なお, 説明課題の順序はブ ランコ,すべり台という順序に固定した。

データの分析 説明課題における対象児の発話と ジェスチャーは, ソニー製のデジタルビデオカメラに よって録画された。ビデオ記録から, 発話を書きおこ し，その文節数を集計し，発話時間（秒）を計測した。

ジェスチャーの分類 次に観察されたジェスチャー から，映像的ジェスチャーを同定した。藤井 (1999) に

2 カバーにかけられた窓の大きさは 3 つのカバーすべてで同 じだったので, 3 つ場合の違いは, 絵のどの位置が窓から見え るかによる違いである 
よれば，映像的ジェスチャーとは，表現対象の形態や 動作を絵のように視覚的に表しているものであり，例 えば両手で球を包むようにして「ボール」を表したり， 手を下から上に動かし「登っていく」という動作を表 すものである。そして, 同定された映像的ジェスチャー を，McNeill (1992) および藤井 $(1999,2000,2002)$ を参 考に，表現対象をどのような視点で捉えてイメージ化 し聞き手に示そうとしているかという視点の違いに よって,以下の 2 種類に分類した。(a)主観的視点のジェ スチャー：自らの手は手としての機能しか持たないと いうように，あたかも自分が対象と関わっているかの ように自分を中心として対象を捉え，身体の前後左右 に大きく描く。例えば, ブランコを表現する際に, 自 分のお尻の下に椅子, 身体の横に 2 本のチェーンを示 し，あたかも自分がブランコに乗っているかのように， 描いた 2 本のチェーンを握って身体を前後に動かす, といったものである。(b)客観的視点のジェスチャー： 自らの手は対象を象徵的に表現するために道具として 使用され，表現対象を外側から捉え，身体の前でミニ チュアのように描く。ブランコの場合, 身体の前方空 間（胸の前あたり）に，主に人差し指を使って 2 本の チェーンと椅子を小さく描く, といったジェスチャー が典型である。

なお，本研究ではジェスチャーを，ブランコとすべ り台という説明対象を表現する際に表出する手の動き に限定して観察した。

\section{結果}

\section{説明課題}

まず，各年齢群の対象児が説明に要した発話時間・ 文節数・ジェスチャー数・単位時間（秒）当たりのジェ

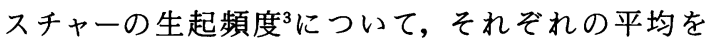
TABLE 1 に示した。それぞれに関して，年齢 $(2$ : 年中・ 年長) $\times$ 課題 (2:ブランコ・すべり台) の 2 要因分散分析を 行ったところ, 発話時間, 文節数, ジェスチャー数に 関しては有意な主効果および交互作用は見られなかっ たが，単位時間 (秒) 当たりのジェスチャーの生起頻度 に関しては年齢の主効果が有意となり，年長児より年

\footnotetext{
3 「単位時間 (秒) 当たりのジェスチャーの生起頻度」とは, 説 明課題において生起した全ジェスチャー数を, 発話時間 (秒) で除したものである。ジェスチャーの数は, 発話時間が長けれ ば長いほど多くなるが，そうではなく，同じだけの発話にどれ だけジェスチャーを伴わせやすいかを見る指標として,この研 究領域では「単位時間 (秒) 当たりのジェスチャーの生起頻度」 という測度が用いられてきた (例えば, 藤井 $(1999,2000,2002)$ やMcNeill (1992))。今回もそれに做いこの測度を設定した。
}

TABLE 1 発話時間・文節数・ジェスチャー数・ジェ スチャ一生起頻度の平均

\begin{tabular}{lrcrc}
\hline & \multicolumn{2}{c}{ 年中 } & \multicolumn{2}{c}{ 年長 } \\
\cline { 2 - 5 } & 平均 & 標準偏差 & 平均 & 標準偏差 \\
\hline 発話時間(秒) & 18.8 & 7.3 & 21.6 & 19.3 \\
文節数 & 17.7 & 7.6 & 20.0 & 22.6 \\
ジェスチャー数 & 5.8 & 4.7 & 4.0 & 4.6 \\
生起頻度 & 0.29 & 0.20 & 0.16 & 0.13 \\
\hline
\end{tabular}

TABLE 2 年齢群ごとの映像的ジェスチャーの生起頻 度

\begin{tabular}{ccccc}
\hline & \multicolumn{2}{c}{ 年中 } & \multicolumn{2}{c}{ 年長 } \\
\cline { 2 - 5 } & 平均 & 標準偏差 & 平均 & 標準偏差 \\
\hline 生起頻度 & 0.21 & 0.19 & 0.12 & 0.11 \\
\hline
\end{tabular}

中児においてジェスチャーの生起頻度が高かった（F $(1,35)=5.40, p<.05)$ 。それぞれの分析において, 課題の 主効果および交互作用が有意でなかったことから，こ こではブランコとすべり台の両者を等質な材料とみな し，以下の分析を行った。次に，月齢とジェスチャー の生起頻度との相関係数を算出したところ $r=$ -.4（ $p<.05 ）$ となり，幼児期では加齢とともにジェス チャーの生起頻度が減少することが示された。さらに, 同定された映像的ジェスチャーの生起頻度を TABLE 2 に示した。この同定は,著者の一人と心理学専攻の大 学院生の 2 名が独立に行い，一致率は $87 \%$ であった。 不一致箇所は協議の上，一致させた。

\section{認知的役割取得課題}

課題に対する反応パタンから Taylor（1988）の基準 (TABLE 3)に従い, 各対象児をレベル 1 とレベル 2 に分 類した。レベル 1 の段階にある幼児は，もし他者が対 象を見なければ，その人は対象について何も知り得な いことは理解できるが，対象が何であるか知るために 必要な視覚的情報とはどのようなものか，については まだ理解できていないと言える。つまり，FIGURE 1 の ような,ゾウの一部しか見ることができない人は，そ

TABLE 3 認知的役割取得能力の各段階への分類基準

レベル 1 レベル 2

窓から見える光景

何も見えない

僅かな部分が見えるが対象を特定て きない

対象を特定できる部分が見える
分からない 分からない

分かる 分からない 分かる 分かる 
れが何の一部なのか, 普通は「分からない」と考えら れるが, この段階の幼児は, 他者がその対象の一部に 視覚的にアクセスできれば，たとえその情報が不十分 なものであっても，その対象が何であるか「分かる」 と推測してしまう。これに対して，レベル 2 の幼児は, 他者が，不十分な情報に接しただけでは対象が何であ るかを知ることができないことを理解しているので, 他者は「分からない」と正しく推測できる。なお， Taylor (1988) の発達段階におけるレベル 1 とレベル 2 以外の反応をした者は，その他として分類した。

その結果は TABLE 4 に示す。年中と年長を比較した ところ, それぞれのレベルの占める割合には偏りがな かった $\left(\chi^{2}(2, N=42)=0.20, p>.1\right)$ 。なお，その他に分類 された対象児 6 名のうち，年中児 3 名は全て「分かる」 と答え, 年長児 3 名は全て「分からない」と答えた。

\section{ジスチャーの視点と認知的役割取得課題との関連}

観察された映像的ジェスチャーがどのような視点に よって産出されているかという, ジェスチャーの視点 の分類は, 筆者と心理学専攻の大学院生の 2 名が独立 に行い, 一致率は $71 \%$ であった。なお, 不一致箇所は 協議の上一致させた。

まず，産出されたジェスチャーの視点と年齢要因と の関連を調べた。FIGURE 2 は, 各年齢群の主観的視点 と客観的視点それぞれによる, 単位時間 (秒) 当たりの ジェスチャーの生起頻度を示したものである。視点

(2) $\times$ 年齢 (2) の分散分析を行ったところ，年齢の主効 果が有意傾向となり, 視点の主客によらずジェス チャーの生起頻度は年中が年長より高い傾向にあるこ とが示された $(F(1,35)=2.98, p<.1)$ 。

次に, 認知的役割取得能力のレベルごとに, 産出さ れたジェスチャーの視点が異なるかを見た。FIGURE 3 は, 各レベルにおけるそれぞれの視点による, 単位時 間 (秒) 当たりのジェスチャーの生起頻度を示したもの である。視点 (2) ×レベル (2) の分散分析を行ったとこ ろ, どちらの主効果も有意とならなかったが, 交互作 用が有意となった $(F(1,29)=6.67, p<.05)$ 。交互作用が 有意であったため, 単純主効果の検定を行った。その 結果, 客観的視点においてレベルの単純主効果が有意

TABLE 4 認知的役割取得能力の各段階にある幼児の 数

\begin{tabular}{cccc}
\hline & \multicolumn{3}{c}{ 反応段階 } \\
\cline { 2 - 4 } クラス & レベル 1 & レベル 2 & その他 \\
\hline 年中 & 8 & 7 & 3 \\
年長 & 12 & 9 & 3 \\
\hline
\end{tabular}

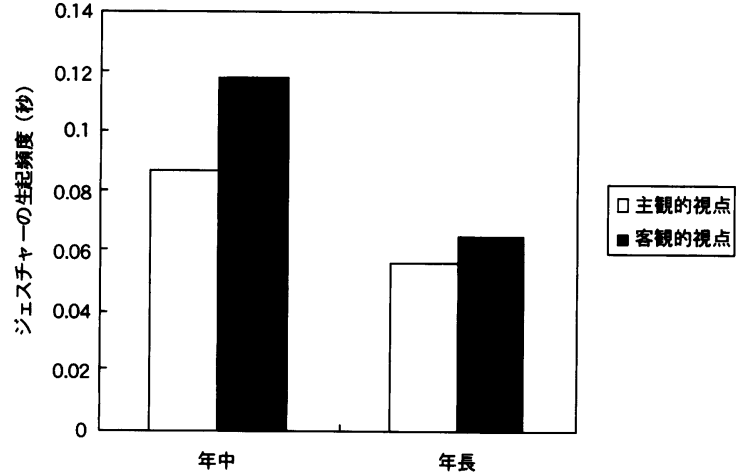

FIGURE 2 年齢群ごとの各視点のジェスチャーの生起 頻度

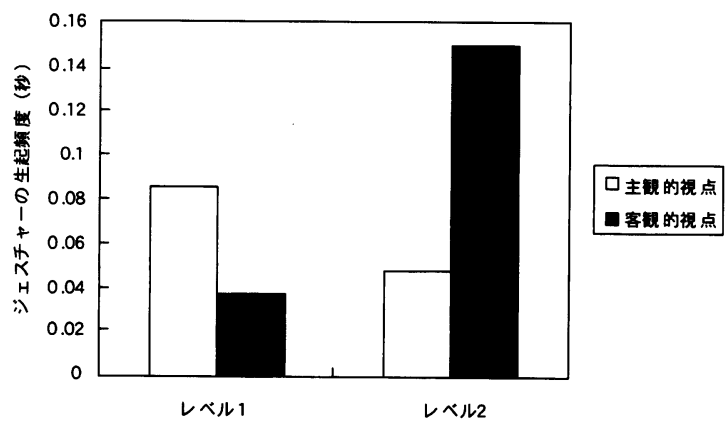

FIGURE 3 レベルごとの各視点のジェスチャーの生起 頻度

で, 客観的視点のジェスチャーは, レベル 1 よりレベ ル 2 の幼児で多く観察されていた $(F(1,29)=6.35$, $p<.05)$ 。また, レベル 2 において視点の単純主効果が 有意となり,レベル 2 の幼児は, 主観的視点のジェス チャーよりも客観的視点のジェスチャーを多く行って いることが示された $(F(1,29)=5.98, p<.05)$ 。

\section{考察}

本研究の目的は, これまで指摘されてきた, ジェス チャーの視点が主観的なものから客観的なものへ移行 するという発達的現象が, 何によって説明できるのか を検討することにあった。そこで, まず年齢群ごとに 対象児の行った説明を分析したところ, 発話時間・文 節数・ジェスチャー数に関しては，年中児と年長児の 間に差は見られなかったが，単位時間当たりのジェス チャーの生起頻度は, 年長児が年中児よりも少なかっ た。これは, ジェスチャーの生起頻度が, 幼児期から 児童期にかけては一旦減少を見せ, 再び増加するU字 
型の発達パタンを示す, という藤井 (1999) が報告した 現象に当てはまるものかも知れない。

次に，主客それぞれの視点によるジェスチャーがど ういった比率で産出されたかを調べたところ, 全体の 平均をとると, 主観的視点のジェスチャーと客観的視 点のジェスチャーが同程度の頻度で産出されていた。 年中児と年長児を比較してみても，それぞれの視点に よるジェスチャーが占める比率に差はなかった。すな わち, 5 歳から 6 歳にかけてのこの時期においては, 両視点のジェスチャーが占める比率に, 年齢差が見ら れなかった。

一方で，認知的役割取得能力についても，年中児と 年長児の間で年齢差は認められなかったが，これらの 結果は, 本研究で対象とした年齢範囲が狭かったため であると考えられる。このように, 両視点のジェス チャーの比率および認知的役割取得課題において年齢 差が見られなかったということから, 他の発達する能 力の影響を排除して, 認知的役割取得能力がジェス チャーの視点に影響しているかどうかを検討するのに 都合の良いデータであったと言える。

そこで，年中児と年長児のデータを込みにして，認 知的役割取得能力の発達段階によって, 主観的視点の ジェスチャーと客観的視点のジェスチャーの生起頻度 に違いがあるかを検討した。その結果, 認知的役割取 得能力がレベル 1 の幼児では, それぞれの視点のジェ スチャーが同程度の頻度で産出されていたのに対し, レベル 2 の幼児では客観的視点のジェスチャーが主観 的視点のジェスチャーと比べてより多く産出されるこ とが示された。このことから, 認知的役割取得能力の レベルによって, 主客どちらの視点のジェスチャーが 産出されやすいか, が異なることが明らかとなり, ジェ スチャーの視点と認知的役割取得能力の発達は関連し ているという本研究の仮説は支持されたと言える。そ して, これまで, 大人は幼児と比較して, 客観的視点 のジェスチャーをより多く, 主観的視点のジェス チャーをより少なく産出するとされてきたが (McNeill, 1992 ; 藤井, 1999), 本研究で得られた結果は, こうした ジェスチャーの視点の発達的移行が, 大人と幼児の認 知的役割取得能力，すなわち，他者が何かを知るため にはどういった情報が必要であるかについての理解の 差異とが関連している可能性を示唆している。

では，なぜ認知的役割取得能力が発達すると, 客観 的視点のジェスチャーの産出が増加するのだろうか。 認知的役割取得能力の発達がどのようにして客観的視 点のジェスチャーの生起頻度を押し上げるかに関して
は, (1)相手の理解に配慮してより多くのジェスチャー をするようになるため，(2)相手の理解や見えに配慮し て表象を操作しジェスチャーするようになるため, と いう 2 つ仮説的なプロセスを想定することができる だろう。以下ではこれら 2 つの可能性について検討す る。

まず，(1)について言うと，幼児は，レベル 1 からレ ベル 2 へと移行することによって, 聞き手の認知プロ セスを哚く意識するようになるので，他者に何かを説 明するという事態において，他者が知ることができる ように試行錯誤し，できる限りの手を尽くして懸命に 伝えようとする。その結果, より多くのジェスチャー が産出されるようになると考えられる。しかし, そも そも主観的視点のジェスチャーはある程度種類が限ら れているため, 増加する分のジェスチャーは客観的視 点のジェスチャーが大半を占めるということになる。 すなわち, 認知的役割取得能力とジェスチャーの視点 とが強く関連しているように見えるが，実際には，む しろジェスチャーの生起頻度との関連が強く, それに 随伴した形で両者の見かけ上の関連が生じているので はないか。

しかし，上述したように，視点(2)×レベル(2)の 2 要 因分散分析において，レベルの主効果が有意とならな かった。このことは認知的役割取得能力の発達段階に よって, 産出されるジェスチャーの生起頻度には差が ないということを示している。このように, 認知的役 割取得能力の発達段階によってジェスチャーの生起頻 度には差が見られず, 客観的視点のジェスチャーの増 加を，全体的なジェスチャー使用の増加から説明する ことはできない。さらに，レベル 1 と 2 の幼児では用 いている視点が質的に異なっていることを示唆する データとして TABLE 5 が挙げられる。これは, 各対象 児について，産出したジェスチャーの視点によって， (a)主観的視点のジェスチャーのみ，(b)客観的視点の ジェスチャーのみ, (c)両方の視点のジェスチャー, (d) 全くジェスチャーをしなかった，というょうにレベル ごとに分類したものである。これに関してフィッ シャーの直接確率法 (両側)による分析を行ったとこ ろ，有意な連関が見られた $(p=.022)$ 。このことから， レベル 1 に比べてレベル 2 では主観的視点のジェス チャーのみを行う人の割合が少なく, 逆に客観的視点 のジェスチャーのみを行う人の割合が多いことが示さ れた。したがって, 客観的視点のジェスチャーが増加 した理由を，認知的役割取得能力の発達に伴う全体的 なジェスチャーの増加に求めるという，(1)の仮説は本 
TABLE 5 認知的役割取得能力の段階とジェスチャー の視点との関係 (人数)

\begin{tabular}{l|cccc}
\hline & 両方 & 主観 & 客観 & なし \\
\hline レベル 1 & 4 & 5 & 0 & 7 \\
レベル 2 & 6 & 1 & 5 & 3 \\
\hline
\end{tabular}

研究で得られたデー夕に照らし合わせてみると, 妥当 ではないと思われる。

それでは(2)の可能性についてはどうだろう。そもそ も, 主観的視点のジェスチャーと客観的視点のジェス チャーを比較してみると, 説明対象についての内的表 象の操作という点において質的に異なっていると考え られる。まず主観的視点のジェスチャーを産出すると いうことは，その説明対象に対する自分の具体的な関 わり方を, 即時的に身体反応として表出する感じに近 く, いわば恐怖状況を想像して顔がひきつるという身 体反応のように，そこには内的表象の操作というプロ セスは介在していないかもしれない。それに対して, 客観的視点のジェスチャーを産出する際には, それを どのように示したら聞き手は「知る」ことができるか を念頭に置いて, 対象についての内的表象を操作して いく必要があるだろう。すなわち, 認知的役割取得能 力がレベル 1 の段階にある幼児は, 聞き手である他者 の存在にはあまり意識が及んでいないので, ジェス チャーを産出する際に, 自らの説明対象についての内 的表象に即時的に身体が反応するため, 主観的視点の ジェスチャーが多い。一方，レベル 2 の幼児は，聞き 手の認知プロセスを意識しているので, 聞き手が何か を知るためには，ジェスチャーという情報をどのよう に提示すれば効果的であるかを推察し, その実現に向 けて内的表象を操作し始める結果, 自己の身体との直 接的な関係が捨象され, 客観的視点のジェスチャーが 産出されると考えられる。

以上見てきたように, 本研究では, ジェスチャーの 視点と認知的役割取得能力との間に関連が存在すると いうことが明らかとなった。しかし，その間にどのよ うなプロセスが働いているのかについての直接的な検 討には至らなかった。よって, 今後は, 両者の間には, 表象操作の発達といった両者に関連する共通した発達 的要因が介在しているのか, あるいは全く異なるプロ セスが働いているのかを検討し, その発達的変化を明 らかにしていくことが必要である。そのためには, 両 者の発達を時系列的に調べていくという縦断的研究や, 訓練をするなどして認知的役割取得能力を操作するこ とによって, ジェスチャーの視点への影響を検討する
ことが必要になってくるものと考えられる。

\section{引用文献}

Chandler, M., \& Helm, D. 1984 Developmental changes in the contributions of shared experience to social role-taking competence. International Journal of Behavioral Development, 7, 145-156.

Flavell, J. H. 1974 The development of inferences about others. In T. Mischel (Ed.), Understanding other persons. Oxford, UK : Basil Blackwell. Pp.66-116.

Flavell, J. H., Botkin, P. T., Fry, C. L., Wright, J. W., \& Jarvis, P. E. 1968 The development of role-taking and communication skills in children. New York : Wiley.

藤井美保子 1999 コミュニケーションにおける身振 りの役割一発話と身振りの発達検討一 教育心理 学研究, 47, 87-96. (Fujii, M. 1999 Effects of gestures in communication : Developmental investigation of speech and gesture. Japanese Journal of Educational Psychology, 47, 87-96.)

藤井美保子 2000 ジェスチャーの産出に関わる社会 的要因の存在: 話者のジェスチャー ジェス チャー生起量と視点の位置に影響を及ほす聞き手 の存在 認知科学, 7(1),65-70. (Fujii, M. 2000 Communicative factors in the production of gestures : The effect of listener's presence on the frequency and the viewpoint of gestures. Cognitive Studies, 7(1), 65-70.)

藤井美保子 2002 ジェスチャーの産出に関わる聞き 手の存在 斉藤洋典・喜多壮太郎（編） ジェス チャー・行為・意味 共立出版 Pp. $80-100$.

喜多壮太郎 2002 人はなぜジェスチャーをするのか 斎藤洋典・喜多壮太郎（編） ジェスチャー・行為・ 意味 共立出版 Pp.1-23.

松村暢隆 1983 概念発達における脱中心化の過程 関西大学文学論集，32(4)，17-35. (Matsumura, M. 1983 The process of decentering in concept. Essays and Studies by Members of the Faculty of Letters, 32(4), 17-35.)

松村暢隆 1984 幼児期における視点取りの発達 関 西大学文学論集, 33(4), 29-48. (Matsumura, M. 1984 Development of perspective-taking in preschool children. Essays and Studies by 
Members of the Faculty of Letters, 33(4), 29-48.)

McNeill, D. 1985 So you think gestures are nonverbal ? Psychological Review, 92, 350-371.

McNeill, D. 1987 Psycholinguistics : $A$ new approach. New York : Harper \& Row. (鹿取 廣人・繁野 純・中越左智子・溝㴊 淳（訳） 1990 心理言語学 サイエンス社)

McNeill, D. 1992 Hand and mind : What gestures reveal about thought. Chicago, IL : University of Chicago Press.

Özyürek, A. 2000 The influence of addressee location on spatial language and representational gestures of direction. In D. McNeill (Ed.), Language and gesture. Cambridge, UK : Cambridge University Press. Pp. 64-83.

斎藤瑞恵 2000 「知っている」ということについての 幼児の理解の発達 発達心理学研究, 11, 163-175. (Saito, M. 2000 The development of understanding of knowing in young children. Japanese Journal of Developmental Psychology, 11, 163-175.)

佐々木正人 1993 「発話に伴う手振り」の現れと視覚 的他者 発達心理学研究, 4, 1-12. (Sasaki, M. 1993 The effect of visual contact with others on the use of hand gestures in speech. Japanese Journal of Developmental Psychology, 4, 1-12.)
Taylor, M. 1988 Conceptual perspective taking : Children's ability to distinguish what they know from what they see. Child Development, 59, 703-718.

Werner, H., \& Kaplan, B. 1974 シンボルの形成 柿崎祐一 (監訳) ミネルヴァ書房（Werner, H., \& Kaplan, B. 1963 Symbol formation : An organismic developmental approach to language and the expression of thought. New York : Wiley.)

山岸明子 1980 役割取得能力の発達に影響する社会 的経験の検討一“役割取得の機会”の観点からの分 析一 心理学研究, 52, 289-295. (Yamagishi, M. 1980 The relationship between role-taking ability and social experience: Analysis in terms of role-taking opportunities. Japanese Journal of Psychology, 52, 289-295.)

\section{謝辞}

本研究にご協力いただいた子どもたちと先生方に心 より御礼申し上げます。

\section{付 記}

本研究は，科学研究費補助 (基盤(B)\#17330139）の補助 を受けた。

(2006.1.18 受稿, 10.23 受理) 


\section{Role-Taking Ability Affects the Viewpoint Children Take When Making Gestures : A Developmental Study}

AKIHIRO KATAYAMA, ETSUKO HARYU (GRADUATE SCHOOL OF EDUCATION, UNIVERSITY OF TOKYO) JAPANESE JOURNAL OF EDUCATIONAL PSYCHOLOGY, 2007, 55, 266-275

Representational gestures during speech can be classified into 2 types according to viewpoint : those conveying an observer's viewpoint, and those expressing a character's viewpoint (Ö̈zyürek, 2000). It has been shown that adults are more likely to make gestures from a character's viewpoint when they are paying attention to what a hearer understands from the perceptual information given (Fujii, 2000). In a developmental study, Fujii (1999) reported that the older that children become, the more gestures they make from a character's viewpoint. Children as they develop might come to be more sensitive to what a hearer can know from the given perceptual information, and this might lead them to take a character's viewpoint more frequently when making gestures. The present study examined this hypothesis. Kindergarten children $(N=43)$ were classified into 2 groups according to their performance on a cognitive role-taking task. Level 2 children were those sensitive to what a hearer could know from the information given ; Level 1 children were those who had not yet reached that level of understanding. The results showed that Level 2 children were more likely than Level 1 children to make gestures from a character's viewpoint, confirming the hypothesis.

Key Words : representational gestures, viewpoint of gestures, cognitive role-taking ability, theory of mind, kindergartners 